\title{
PEROXIDASE ACTIVITY IN MAIZE INBRED LINES RESISTANT OR SUSCEPTIBLE TO MAIZE DWARF MOSAIC VIRUS ${ }^{1}$
}

\author{
ISABEL REGINA PRAZERES DE SOUZA², ELIZABETH DE OLIVEIRA ${ }^{2}$, MARILDA AUGUSTA \\ PERES $^{3}$, ANTÔNIO CARLOS DE OLIVEIRA $^{2}$, ANTÔNIO ÁLVARO CORSETTI PURCINO ${ }^{2}$
}

\author{
${ }^{1}$ Trabalho parcialmente financiado pela Fapemig Processo 885/97 e Prodetab 162-01/98 \\ ${ }^{2}$ Pesquisadores Embrapa Milho e Sorgo. Caixa Postal 151, CEP 35701-970 Sete Lagoas, MG, E-mail: \\ isabel@cnpms.embrapa.br (autor para correspondência). \\ ${ }^{3}$ Pesquisadora, Bolsa RD Fapemig
}

Revista Brasileira de Milho e Sorgo, v.2, n.1, p.1-8, 2003

\begin{abstract}
Peroxidase (EC 1.11.1.7) activity levels were analyzed in maize seedling inbred lines contrasting with their resistance to maize dwarf mosaic virus (MDMV). Groups of noninoculated resistant and susceptible inbred lines showed different levels of guaiacol peroxidase activity at the seedling stage, with $78 \%$ of susceptible inbred lines presenting enzyme activity values below $91.46 \mathrm{~A}_{470} \mathrm{~min}^{-1} \mathrm{~g} \mathrm{FW}^{-1}$. However, the zymogram patterns of peroxidase did not allow the differentiation of non-inoculated resistant or susceptible inbred lines. The virus complex induced a general enhancement of enzyme activity, without qualitative changes in the isoenzymes, when inoculated into resistant or susceptible inbred lines. However, a quantitative change, with $19 \%$ OD average increase in a moderately anionic isoform was observed in some resistant inbred lines in response to virus inoculation. Our results could suggest that peroxidase activity prior to infection, and the increase in activity of an specific anionic isoform in some resistant inbred lines, due to virus inoculation, could be related to a defense mechanism against MDMV.
\end{abstract}

Key words: Zea mays L., potyvirus, isoforms.

\section{ATIVIDADE DA PEROXIDASE EM LINHAGENS DE MILHO RESISTANTES OU SUSCEPTÍVEIS AO MOSAICO COMUM DO MILHO}

RESUMO - Níveis de atividade da peroxidase (EC 1.11.1.7) foram analisados em plântulas de linhagens de milho contrastantes quanto à resistência ao mosaico comum do milho (MDMV). Grupos de linhagens não-inoculadas, resistentes e susceptíveis apresentaram diferentes níveis de atividade da guaiacol peroxidase no estádio de plântulas, com $78 \%$ das linhagens susceptíveis apresentando valores de atividade da enzima abaixo de $91.46 \mathrm{~A}_{470} \min ^{-1} \mathrm{~g} \mathrm{FW}^{-1}$. Entretanto, os padrões dos zimogramas da peroxidase não permitiram a diferenciação de linhagens resistentes ou susceptíveis. O complexo viral, quando inoculado nas linhagens resistentes ou susceptíveis, induziu um aumento geral na atividade da enzima, sem alterações qualitativas nas isoformas. Entretanto, uma alteração quantitativa, com aumento médio de $19 \%$ OD em uma isoforma moderadamente aniônica foi observada em algumas linhagens resistentes, em resposta à inoculação com vírus. Os resultados parecem indicar que, em algumas linhagens resistentes, a atividade da peroxidase antes da infecção e o aumento, devido à inoculação com vírus, na atividade de uma isoforma aniônica específica, podem estar relacionados ao mecanismo de defesa contra MDMV.

Palavras-chave: Zea mays L., potyvirus, isoformas. 
Resistance to some plant diseases is associated with increased peroxidase activity and expression of specific isoenzymes (Ye et al., 1990; Goy et al., 1992). Peroxidase activity as a preliminar biochemical marker may predict resistance of uninfected muskmelon to Pseudoperonospora cubensis (Reuveni et al., 1992) and resistance of maize to gray leaf spot (Garraway and Beltran, 1997). However, studies designed to verify these associations using maize (Zea mays L.) genotypes contrasting their resistance to potyvirus-induced-mosaic are rare. The potyvirus-induced-mosaic is one of the most important diseases in maize due to its ubiquity and imposed yield losses. The common maize viruses can be caused by four distinct potyviruses: Maize dwarf mosaic virus (MDMV), Sugarcane mosaic virus (SCMV), Johnsongrass mosaic virus (JGMV) and Sorghum mosaic virus (SrMV) (Shukla et al., 1994). In Brazil MDMV-B is the most common virus (Melo, 2000; Melo et al.,2000). Most commercial maize cultivars are susceptible to MDMV and yield losses can be as great as 50\% (Waquil et al., 1996). The objectives of this study were: (i) to determine the activity and expression of peroxidase isoenzymes in seedlings of maize inbred lines contrasting with their resistance to MDMV, and (ii) to determine the effect of MDMV infection on the activity and expression of peroxidase isoenzymes in maize leaves.

\section{Material and Methods}

Eighteen MDMV susceptible and 15 resistant maize inbred lines were previous selected from one-thousand maize inbred lines from the breeding program at the National Maize and Sorghum Research Center/Brazilian Agricultural Corporation. These lines had been screened by inoculating MDMV onto seedlings, 7 days after sowing. Evaluations for the presence of mosaic symptoms were made 15 days post-inoculation. Three seedlings of each genotype were evaluated three times throughout the year under different climatic conditions. Only inbred lines completely free of MDMV disease symptoms in all three plants at each of the three evaluations were considered resistant to MDMV.

Inoculum was obtained from the leaves of 30 days old field-grown maize hybrid plants expressing strong symptoms of MDMV. Inoculum was prepared by macerating infected leaves in 10 $\mathrm{mM}$ phosphate buffer at $\mathrm{pH} 7.0$ to a ratio $1: 5(\mathrm{w} / \mathrm{v})$. Plants were inoculated by gently rubbing, approximately $1 \mathrm{ml}$ of inoculum over the seedling leaf surface, after youngest upper leaves had been gently wounded with 600 mesh carborundum, and subsequently rinsed with sterile water (Almeida et al., 2000).

Peroxidase activity and isoenzyme expression was measured in non-inoculated maize inbred lines resistant and susceptible to MDMV. This experiment was carried out in an greenhouse under controlled conditions (radiance of $500 \mu \mathrm{mol} \mathrm{m}^{-2} \mathrm{~s}^{-1}$ supplied by $100 \mathrm{~W}$ incandescent lamps, diurnal temperature $28^{\circ} \mathrm{C}$, night temperature $18^{\circ} \mathrm{C}$, relative humidity $60 \%$ ). Fifteen resistant and 18 susceptible maize inbred lines were used. Six seeds of each genotype were sowed per pot and thinned to three seedlings after germination. The treatment was completely randomized with three replicates per treatment. Enzyme activity and expression of isoenzymes were determined in the third leaf of each genotype in 17 day-old seedlings.

Effect of MDMV infection on peroxidase activity and expression of peroxidase isoenzymes in maize inbred lines resistant or susceptible to potyvirus-induced-mosaic. This experiment was carried out under the greenhouse conditions described above. Four resistant $(\mathrm{R})$ maize inbred lines: $161,505,516,575$, and five susceptible (S): $8,22,38,40,43$ were used, and six seeds of each genotype were sowed per pot and thinned to three 
seedlings after germination. The inoculation treatments were imposed to the youngest leaf on the $7^{\text {th }}$ day after sowing. The treatments were completely randomized, with 3 replicate pots per treatment, and included: non-inoculation, buffer after gentle wounding with carborundum, and inoculation after gentle wounding with carborundum. Eight days after inoculation the susceptible inbred lines showed symptoms of viral infection. The third leaf from each seedling, on the $17^{\text {th }}$ day after sowing, was collected for extraction of total soluble and ionically bound protein.

Soluble plus ionically bound protein fractions were extracted from $0.3 \mathrm{~g}$ of the third leaf, ground in liquid $\mathrm{N}_{2}$ and suspended in two volumes of $50 \mathrm{mM}$ phosphate buffer, $\mathrm{pH} 6.0$, containing $1 \mathrm{mM}$ phenylmethylsulfonyl fluoride (PMSF), $1 \mathrm{M} \mathrm{NaCl}$ and $1.5 \%$ polyvinylpolypyrrolidone (PVPP) $(\mathrm{w} / \mathrm{v})$. The homogenate was centrifuged at $14000 \mathrm{~g}$ at $4^{\circ}$ $\mathrm{C}$ for $30 \mathrm{~min}$, and the supernatant containing the total soluble and ionically bound protein fraction retained for analysis. Seedlings were preserved by using the third leaf for analyses, based on the possibility of peroxidase activity being a biochemical marker for resistance.

For isoelectric focusing $150 \mu \mathrm{l}$ of the protein extracts were desalted and concentrated to $36 \mu \mathrm{l}$ through microcon-10 filters (Millipore Corporation, Bedford, MA) before being subjected to electrophoresis. Fifteen $\mu \mathrm{g}$ of protein of the leaf extract, approximately $5 \mu$, from each sample was loaded onto a $1 \%$ agarose native gel prepared with $12 \%$ sorbitol (w/v) and $6.7 \%$ ampholytes (v/v) in the 3 to $10 \mathrm{pH}$ range (Amersham Pharmacia Biotech, Piscataway, NJ, USA). Gels were cast onto Gelbond using a mold $125 \times 260 \times 1 \mathrm{~mm}$ (Amersham Pharmacia Biotech, Piscataway, NJ, USA) and were run in Multiphor II (Amersham Pharmacia Biotech, Piscataway, NJ, USA). Gel prefocusing was done for $20 \mathrm{~min}$ at $1200 \mathrm{~V} / 1 \mathrm{~W}$ and focusing for 2 hours at $1200 \mathrm{~V} / 4 \mathrm{~W}$ at $10^{\circ} \mathrm{C}$. After electrophoresis the gel was stained for peroxidase activity using the PPDPC protocol (Imberty et al., 1984). The quantification of peroxidase isoenzymes in the gel was carried out by determining the optical density (OD) of the peak height using the personal densitometer SI (Amersham Pharmacia, NJ, USA).

Peroxidase activity was assayed as described by Souza and MacAdam (1998) at $30^{\circ} \mathrm{C}$ in a $1 \mathrm{ml}$ reaction mixture containing $96 \mathrm{mM}$ potassium phosphate buffer $\mathrm{pH} 6.0,3.2 \mathrm{mM}$ guaiacol, and $0.38 \mathrm{mM}$ hydrogen peroxide. The reaction was initiated by adding $10 \mu \mathrm{l}$ protein extract to the reaction mixture, and the increase in absorption of guaiacol min ${ }^{-1}$ was measured at $\mathrm{A}_{470} \mathrm{~nm}$.

The presence of potyviruses associated with mosaic symptoms was confirmed through transmission electron microscope analysis using "leaf dip" preparations stained with $2 \%$ phosphotungistic acid and by dot Enzyme-linked immunosorbent assay (ELISA), using specific IgG against these viruses, as described by Almeida et al. (2000).

The variance analysis was realized by using the GLM procedure (SAS INSTITUTE, 1993). The Scott \& Knott (1974) test, that allows comparisons of the treatment means to form independent and homogeneous clusters, was applied to peroxidase activity to verify the separation of the maize inbred lines in clusters of the susceptible and resistant to MDMV.

\section{Results and Discussion}

\section{Peroxidase activity and expression of its isoenzymes in non-inoculated maize inbred lines resistant or susceptible to MDMV.}

All data were analyzed by ANOVA. Where ANOVA indicated that peroxidase activity differed significantly $(\mathrm{P}<0.01)$ without inoculation between maize inbred lines resistant or susceptible to MDMV. The highly significant $(\mathrm{P}<0.01)$ interaction between 
the susceptible and resistant inbred lines (S vs R), indicates that the difference in peroxidase activity was larger between the resistant and susceptible groups than within each one of these groups. The separation of clusters by the Scott and Knott test resulted in a large number of susceptible inbred lines (78\%) with peroxidase activity values below $91.46 \mathrm{~A}_{470} \mathrm{~min}^{-1} \mathrm{~g}^{-1}$ FW and resistant inbred lines $(60 \%)$ with peroxidase activity above this value (Table 1 ). This difference suggests that in some inbred lines, peroxidase could be involved as one of the resistance mechanisms to this maize virus. Peroxidase activity could be related to a fast production of physical barriers involved in avoiding virus translocation through the plant restricting it to the localized region of infection. Lignin synthesis (Whitmore 1978; Siegel, 1953), oxidative coupling reactions involving phenolics that are esterified to wall polysaccharides (Geissman and Neukon, 1971; Hartley 1973; Fry 1982a), and the formation of isodityrosine bridges that are believed to crosslink extensin molecules (Fry 1982b) are among the functions proposed for peroxidase that could be responsible for reinforcements of the cell wall as a barrier to the viruses. However, it is likely that other mechanisms of resistance are also involved in conferring resistance in the resistant maize inbred lines, since $40 \%$ of these had peroxidase activities lower than $91.46 \mathrm{~A}_{470} \mathrm{~min}^{-1} \mathrm{~g}^{-1} \mathrm{FW}$ (Table 1). The mean peroxidase activity for the group of resistant genotypes was $97.359 \mathrm{~A}_{470} \mathrm{~min}^{-1} \mathrm{~g}^{-1} \mathrm{FW}$ whereas for the group of susceptible genotypes it was 75.301 $\mathrm{A}_{470} \min ^{-1} \mathrm{~g}^{-1} \mathrm{FW}$. Therefore, these results indicate that the resistant genotypes on average had higher $(29.30 \%)$ peroxidase activity than the group of susceptible genotypes. Apparent susceptibility could be related to a low level of peroxidase activity prior to infection (Table 1). Similar results were obtained when peroxidase activities were calculated between groups of muskmelon genotypes varying in their resistance to Pseudoperonospora cubensis
TABLE 1. Peroxidase activity levels in non-inoculated maize seedling inbred lines susceptible (S) or resistant (R) to MDMV.

\begin{tabular}{ccc}
\hline Inbred line & $\begin{array}{c}\text { Peroxidase activity } \\
\left(\mathrm{A}_{470} \min ^{-1} \mathrm{gW}^{-1}\right)\end{array}$ \\
\hline $520(\mathrm{R})$ & 173.70 & $\mathrm{a}$ \\
$134(\mathrm{R})$ & 130.20 & $\mathrm{a}$ \\
$505(\mathrm{R})$ & 117.20 & $\mathrm{a}$ \\
$18(\mathrm{R})$ & 113.90 & $\mathrm{a}$ \\
$26(\mathrm{~S})$ & 110.70 & $\mathrm{a}$ \\
$402(\mathrm{R})$ & 103.80 & $\mathrm{a}$ \\
$215(\mathrm{R})$ & 102.30 & $\mathrm{a}$ \\
$39(\mathrm{~S})$ & 99.38 & $\mathrm{a}$ \\
$406(\mathrm{R})$ & 99.03 & $\mathrm{a}$ \\
$454(\mathrm{R})$ & 98.40 & $\mathrm{a}$ \\
$40(\mathrm{~S})$ & 98.19 & $\mathrm{a}$ \\
$20(\mathrm{R})$ & 94.03 & $\mathrm{a}$ \\
$16(\mathrm{~S})$ & 91.46 & $\mathrm{a}$ \\
$\mathrm{L} 20(\mathrm{~S})$ & 81.39 & $\mathrm{~b}$ \\
$33(\mathrm{~S})$ & 78.61 & $\mathrm{~b}$ \\
$38(\mathrm{~S})$ & 79.46 & $\mathrm{~b}$ \\
$1(\mathrm{~S})$ & 76.18 & $\mathrm{~b}$ \\
$258(\mathrm{R})$ & 75.52 & $\mathrm{~b}$ \\
$431(\mathrm{R})$ & 73.82 & $\mathrm{~b}$ \\
$30(\mathrm{~S})$ & 72.64 & $\mathrm{~b}$ \\
$22(\mathrm{~S})$ & 72.01 & $\mathrm{~b}$ \\
$20-50(\mathrm{R})$ & 71.81 & $\mathrm{~b}$ \\
$8(\mathrm{~S})$ & 71.53 & $\mathrm{~b}$ \\
$2(\mathrm{~S})$ & 70.90 & $\mathrm{~b}$ \\
$516(\mathrm{R})$ & 70.83 & $\mathrm{~b}$ \\
$28(\mathrm{~S})$ & 69.31 & $\mathrm{~b}$ \\
$29(\mathrm{~S})$ & 68.96 & $\mathrm{~b}$ \\
$257(\mathrm{R})$ & 68.13 & $\mathrm{~b}$ \\
$161(\mathrm{R})$ & 67.71 & $\mathrm{~b}$ \\
$19(\mathrm{~S})$ & 62.50 & $\mathrm{~b}$ \\
$17(\mathrm{~S})$ & 59.17 & $\mathrm{~b}$ \\
$15(\mathrm{~S})$ & 57.29 & $\mathrm{~b}$ \\
$25(\mathrm{~S})$ & 35.73 & $\mathrm{~b}$ \\
\hline & &
\end{tabular}

a, b Means within column followed by the same letter belongs to the same cluster according to Scott \& Knott test. Data are the means of three replications. 
(Reuveni et al., 1992), between maize genotypes varying in their resistance to Cercospora Zeaemaydis (Garraway and Beltran, 1997), between lettuce genotypes contrasting in their resistance to downy mildew (Reuveni et al., 1991), and in Nicotiana hybrid resistance to several diseases has been linked to high levels of peroxidase (Goy et al., 1992). Some peroxidase isoforms have also been associated with disease resistance. In maize, resistance to northern leaf blight was associated to an specific isoform (Bar-Zur et al. 1998) and resistance to Exesrohilium turcicum was correlated to peroxidase banding patterns (Shimoni et al. 1996). Collectively these results indicate that increased peroxidase activity and expression of specific isoenzymes may be a constitutive mechanism used by plants against severe, pathogen infection. In our study the zymogram pattern of the peroxidase isoenzymes showed polymorphism but did not allow the group separation of non-inoculated susceptible and resistant inbred lines (data not shown).

\section{Effect of MDMV infection on peroxidase activity and expression of its isoenzymes in maize inbred lines resistant or susceptible to MDMV}

Peroxidase activity did not increase significantly $(\mathrm{P}>0.05)$ after the carborundum treatment (Table 2) but increased significantly
$(\mathrm{P}<0.01)$ in the $\mathrm{R}$ and $\mathrm{S}$ inbred lines after inoculation with MDMV as indicated by ANOVA. These observations indicate that the presence of the virus was responsible for the increase in peroxidase activity in susceptible and resistant maize inbred lines. The significant $(\mathrm{P}<0.01)$ difference ( $\mathrm{S}$ vs. $\mathrm{R}$ groups) showed that resistant and susceptible lines to MDMV gave different patterns in peroxidase activity related to treatments. In the virus-inoculated treatment, the resistant inbred lines on average exhibited more peroxidase activity than the susceptible lines, although this difference was not significant (Table 2). Although, in this study there was an increase in peroxidase activity in the susceptible inbred lines after inoculation, it would not be sufficient to stop the virus spreading. These results are in agreement with the inoculation of tobacco leaves with tobacco mosaic virus (TMV) leading to an increase in peroxidase activity (Ye et al. 1990), inoculation of okra with yellow vein mosaic virus (Ahmed et al. 1992), and inoculation of maize with E. turcicum (Shimoni et al. 1996). These studies all show that increased peroxidase activity occur in both resistant and susceptible genotypes. These observations suggest that this enzyme may play a role in plant defense against MDMV. Peroxidase is involved in the final steps of lignin biosynthesis and reinforcement of the cell wall, and is frequently mentioned as a mechanism of resistance (Vance et al. 1980). Peroxidase activity

TABLE 2. Mean peroxidase activity levels in virus-inoculated maize seedling inbred lines susceptible (S) or resistant (R) to MDMV.

\begin{tabular}{cccc}
\hline \multirow{2}{*}{ Treatment } & \multicolumn{3}{c}{$\begin{array}{c}\text { Peroxidase activity } \\
\left(\mathrm{A}_{470} \mathrm{~min}^{-1} \mathrm{~g} \mathrm{FW}^{-1}\right)\end{array}$} \\
\cline { 2 - 4 } & $\mathrm{S}$ & $\mathrm{R}$ & Means \\
\hline Non-inoculation & 49.9 & 49.9 & $49.9 \mathrm{~b}$ \\
Carborundum & 48.2 & 54.6 & $51.4 \mathrm{~b}$ \\
Inoculation & 57.9 & 62.4 & $60.2 \mathrm{a}$ \\
\hline
\end{tabular}

$\mathrm{CV}=8.84 \%$. Means within column followed by the same letter are not significantly different by the Tukey test at $\mathrm{P}<05$. The treatmentes were: non-inoculation, carborundum and inoculation with MDMV. Data are the means of three replications. 
also increases locally and systematically in plants carborundum or inoculation treatments, as the infected with various pathogens (Candela et al. 1994; zymograms in the susceptible (Fig. 1A) and resistant Ye et al. 1990). In the present study, the peroxidase (Fig. 1B) lines, didn't show any qualitative changes isoforms were not induced or repressed by the in peroxidase isoenzyme patterns among treatments.

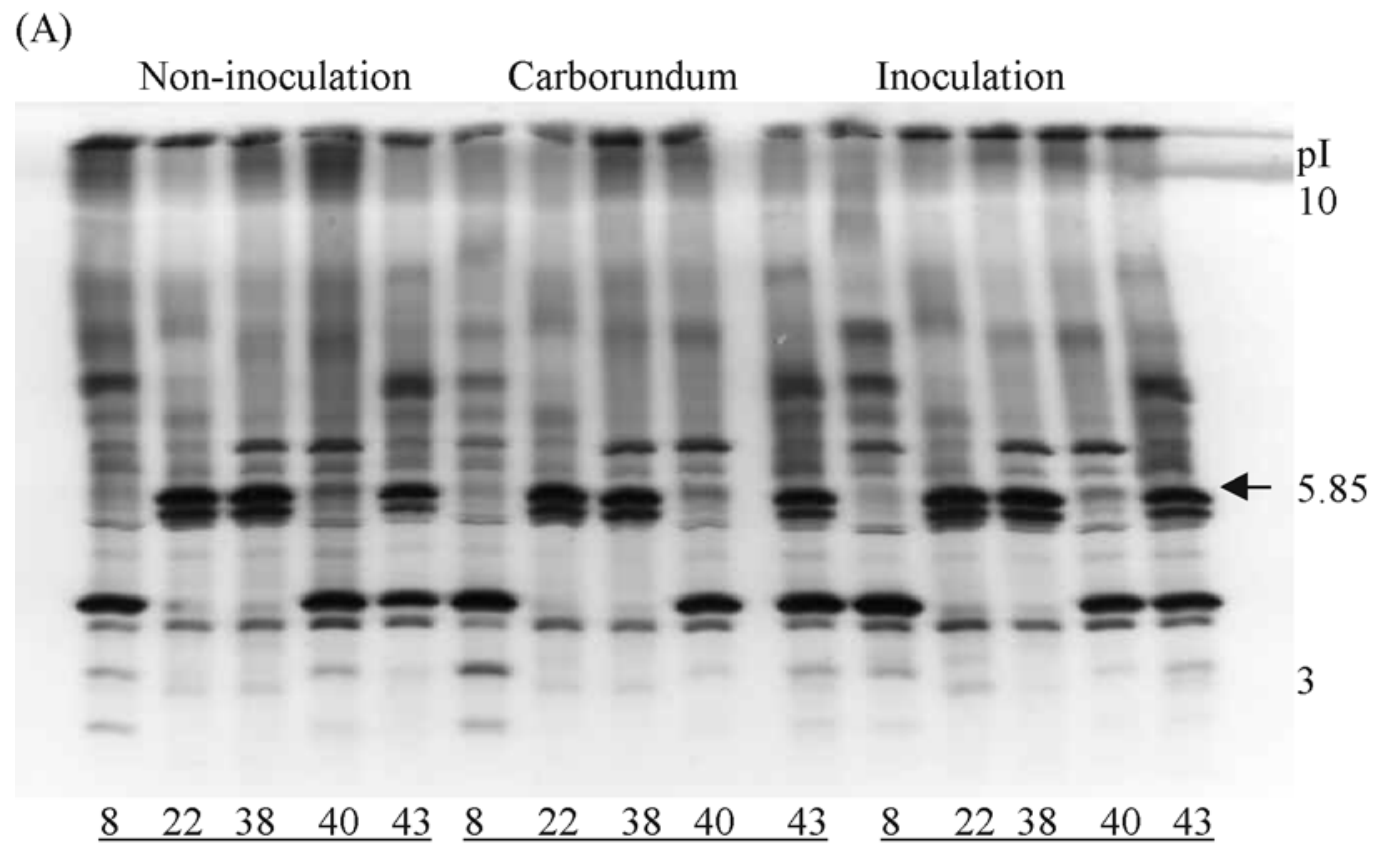

(B)

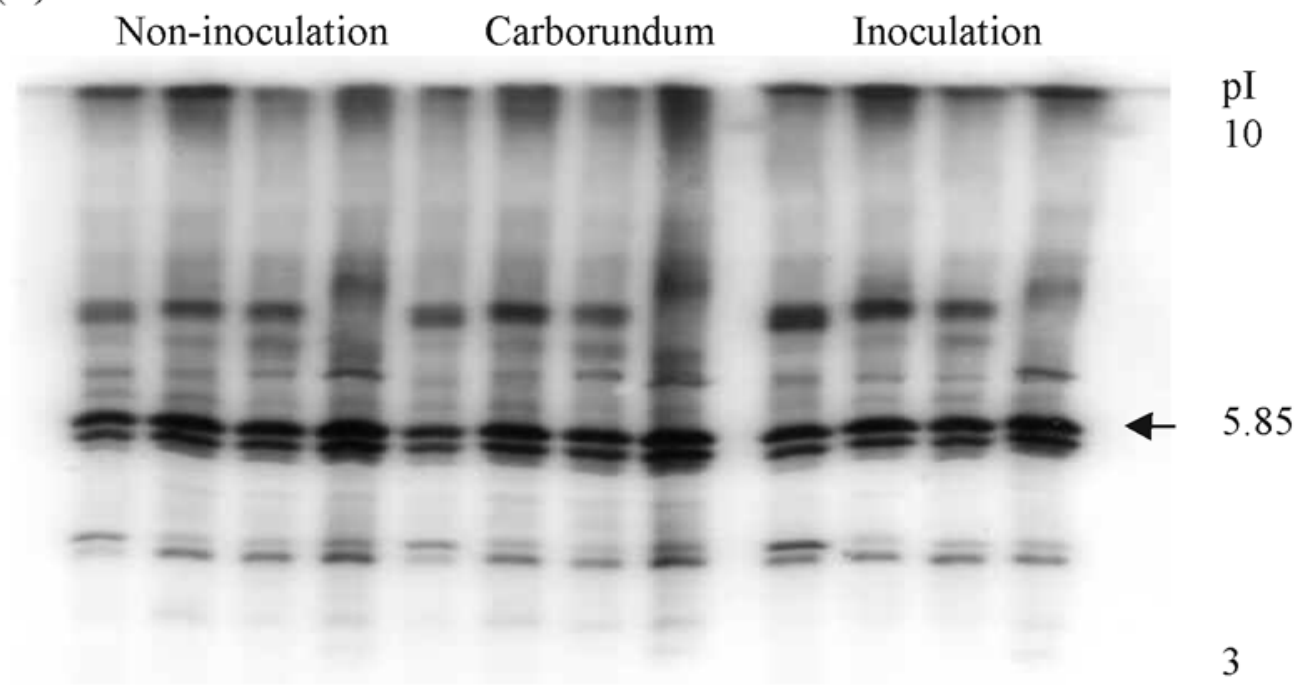

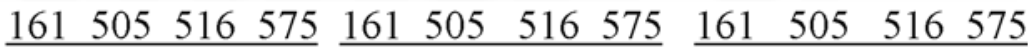

FIGURE 1. Zymogram of peroxidase isoenzymes from maize seedling inbred lines susceptible (A) or resistant (B) to MDMV submitted to three different treatments: non-inoculation, carborundum and inoculation with MDMV. Arrow shows an anionic isoform (pI 5.85) that in resistant inbred lines showed an 19\% average increase in OD peak in response to virus inoculation. 
However, a constitutive anionic peroxidase isoform (pI 5.85) from some resistant inbred lines (Fig. 1B) showed an $19 \%$ average increase on OD peak due to virus inoculation. Moderately anionic isozymes has been shown to have high affinity for the cell wall, with both ionic and covalent interactions (Birecha and Miller, 1974). An enhanced peroxidase activity is probably important in the reinforcement of the cell wall to prevent the virus from spreading.

\section{Conclusions}

Our results seem to indicate that, in some resistant inbred lines, peroxidase activity prior to infection, and increase in activity of a specific anionic isoform, due to virus inoculation, could be related to a defense mechanism against to MDMV.

\section{References}

AHMED, N.; THAKUR, M.R.; BAJAJ, K.L.; CHEEMA, S.S. Biochemical basis of resistance to yellow vein mosaic virus in okra. Plant Disease Research, Ludhiana, v. 9, p. 20-25, 1992.

ALMEIDA, A. C. L; OLIVEIRA, E.; RESENDE, R.O. Detecção de vírus por RT-PCR, hibridização "dot-blot" e dot-Elisa em milho com mosaico comum. Fitopatologia Brasileira, Brasilie, v 25, p. 168-174, 2000.

BAR-ZUR, A.; TADMOR, Y.; JUVIK, J. A.; SHIMONI, M.; REUVENI, R. Resistance to Northern leaf blight in maize (Zea mays) conditioned by the $H t N$ gene and the association with isoperoxidases. Canadian Journal of Plant Pathology, Ottawa, v. 20, p. 28-34, 1998.

BIRECHA, H.; MILLER, A. Cell wall and protoplast isoperoxidases in relation to injury indoleacetic acid and ethylene effects. Plant Physiology, Bethesda, v. 53, p.569-574, 1974.

CANDELA, M.E.; MUÑOZ, R.; ALCÁZAR, M.D; ESPÍN, A. Isoperoxidases involvement in the resistance of Capsicum annuum to infection by cucumber mosaic virus. Journal of Plant Physiology, Stuttgart, v. 144, p. 213-217, 1994.

FRY, S.C. Isodytirosine, a new cross-linking amino acid from plant cell-wall glycoprotein. Biochemical Journal, London, v. 204, p. 449-455, 1982 a.

FRY, S.C. Phenolic components of the primary cell wall. Feruloylated disaccharides of D-galactose and L-arabinose from spinach polysaccharide. Biochemical Journal, London, v. 203, p. 493-504, 1982 b.

GARRAWAY, M. O; BELTRAN, J. D. Peroxidase activity in selected maize cultivars may predict resistance to gray leaf spot. Phytopathology, St. Paul, v. 87, p. 32, 1997. Suplement.

GEISSMAN T; NEUKON H. Vernetzung von Phenolcarbonsaureestern von Polysaccharidendurch oxydative phenolicshe kupplung. Helvetica Chimica Acta, Zürich, v. 54, p. 112-113, 1971.

GOY, P. A.; FELIX, G.; MÉTRAUX, J. P.; MEINS, JR. F. Resistance to disease in the hybrid Nicotiana glutinosa $x$ Nicotiana debneyi is associated with high constitutive levels of Beta-1,3-glucanase, chitanase, peroxidase and polyphenoloxidase. Physiological and Molecular Plant Pathology, Orland, v. 41, p. 11-21, 1992.

HARTLEY, R. D. Carbohydrates esters of ferulic acid as components of cell-walls of Lolium multiflorum. Phytochemistry, Elmsford, v. 12, p. 661-665, 1973.

IMBERTY, A.; GOLDBERG, R; CATESSON, A.$\mathrm{M}$. Tetramethylbenzidine and $\mathrm{p}$-phenylenediaminepyrocatechol for peroxidase histochemistry and biochemistry: two new, non-carcinogenic chromogens for investigating lignification process. Plant Science Letters, Amsterdam, v. 35, p. 103108, 1984. 
MELO, P.R. de. Estudo da variabilidade e do uso de métodos moleculares na detecção dos vírus do rayado fino e do mosaico comum do milho (Zea mays L.). 2000. 103 f. Dissertação (Mestrado em Fitopatologia) - Universidade de Brasília, Brasilie.

MELO, P. R. DE; OLIVEIRA, E.; RESENDE, R. O. Virose do mosaico comum do milho no Brasil: caracterização e incidência. Characterization and incidence of potyvirus-induced mosaic in maize crops of Brazil. Fitopatologia Brasileira, Brasília, v. 25, p. S444, 2000.

REUVENI, R.; SHIMONI, M.; CRUTE, I. R. An association between high peroxidase activity in lettuce (Lactuca sativa) and field resistance to downy mildew (Bremia lactucae). Journal of Phytophatology, Berlim, v. 132, p, 312-318, 1991.

REUVENI, R.; SHIMONI, M.; KARCHI, Z; KUÉ, J. Peroxidase activity as a biochemical marker for resistance of muskmelon (Cucumis melo) to Pseudoperonospora cubensis. Phytopathology, St. Paul, v. 82, p. 749-753, 1992.

SAS INSTITUTE. SAS/STAT User's guide. Version 6.12. 4 ed. Carey, 1993. 846p.

SCOTT, A. J. AND KNOTT, M. A. A cluster analysis method for grouping means in the analysis of variance. Biometrics, Raleigh, v. 30, n.3, p. 5 07-512, 1974.

SHIMONI, M., REUVENI, R.; BAR-ZUR, A. Relation between peroxidase, Beta-1,3-glucanase, the se gene and partial resistance of maize to
Exserohilium turcicum. Canadian Journal of Plant Pathology, Ottawa, v. 18, p. 403-408, 1996.

SHUKLA, D. D.; WARD, C.W. AND BRUNT A. A. The potyviridae. Cambridge: University Press, 1994. 516 p.

SIEGEL, S.M. On the biosynthesis of lignins. Physiology Plantarum, Copenhagem, v. 6, p. 135139, 1953.

SOUZA, I.R.P.; MACADAM, J.W. A transient increase in apoplastic peroxidase activity precedes decrease in elongation rate of $\mathrm{B} 73$ maize (Zea mays L.) leaf blades. Physiologia Plantarum, Copenhagem, v. 104, p. 556-562, 1998.

VANCE, C.P.; KIRK, T.K.; SHERWOOD, R.T. Lignification as a mechanism of disease resistance. Annual Review of Phytopathology, Palo Alto, v. 18, p. 259-288, 1980.

WAQUIL, J.M., OLIVEIRA, E., PINTO, F.F.J.A, FERNANDES, F.T. E CORREA, L.A. Viroses em milho-incidência e efeito na produção. Fitopatologia Brasileira, Brasília, v. 20, p. 292-293, 1996.

WHITMORE, F.W. Lignin-protein complex catalyzed by peroxidase. Plant Science Letters, Awsterdam, v. 13, p. 241-245, 1978.

YE, X. S.; PAN, S.Q.; KUC, J. Activity, isozyme pattern, and cellular localization of peroxidase as related to systemic resistance of tobacco to blue mold (Peronospora tabacina) and to tobacco mosaic virus. Phytopathogy, St. Paul, v. 80, p. 1295-1299, 1990. 